Fisher; fatty acid metabolism by Drs. S. J. Folley and A. L. Greenbaum and the mechanism of the action of insulin by Dr. P. J. Randle and Prof. F. G. Young. Prof. F. G. Young has acted as scientific editor of this issue.

\section{Inhibition of Development in Rust Fungi}

D. J. SAmborskr and F. R. Forsyth have reported on the inhibition of the development of rust fungi, on detached wheat leaves, by various metabolites, antimetabolites and enzyme poisons (Canad. J. Bot., $38,467 ; 1960)$. This is part of a series of investigations in which attempts are being made to correlate changes in the reaction of the pathogen with changes in endogenous levels of substrate in the host. In the experiments, detached leaves of Little Club wheat were floated on solutions containing benzimidazole and the compound being tested. The effects of purine and pyrimidines, vitamins, amino-acids, carbohydrates and enzyme poisons were examined. A number of these compounds inhibited leaf and stem rusts at concentrations that were not injurious to the host. Of the purines and pyrimidines tested, thymine and the analogue azathymine were the only effective inhibitors. The antivitamin oxythiamine was inhibitory, the inhibition being completely reversed by thiamine. A few natural amino-acids, notably histidine, isoleucine, methionine and serine, inhibited rust development. The inhibition was reversed by glycine in all cases except with serine. Amino-acid analogues, particularly canavanine, ethionine and $p$-fluorophenylalanine, were very good inhibitors, the inhibitions being reversed by comparable levels of arginine, methionine and phenylalanine, respectively. The carbohydrates lyxose, xylose, sorbose, and all the sugar alcohols tested were effective inhibitors of rust development. Of the enzyme poisons tested, sodium fluoride and sodium azide differentially inhibited rust growth.

\section{The Gairdner Foundation : Awards}

AWARDs totalling 30,000 dollars for medical work in arthritis and heart disease have been made by the Gairdner Foundation to four American and two British medical scientists as follows: Prof. John H. Gibbon, jun., professor of surgery and director of surgical research, Jefferson Medical College, Philadelphia; Prof. William F. Hamilton, professor of physiology, University of Georgia School of Medicine; Dr. Karl Meyer, dean of medicine at Columbia University, New York; Prof. Arnold R. Rich, Baxley professor emeritus of pathology, Johns Hopkins University; Prof. J. McMichael, professor of medicine, University of London; Prof. J. H. Burn, recently professor of pharmacology, University of Oxford. The awards will be worth 5,000 dollars each, and are prizes for achievements rather than for the support of future research.

\section{U.S. Society for the Study of Development and Growth}

THE following were elected officers of the U.S. Society for the Study of Development and Growth for the year November 1960-November 1961: president, Prof. William P. Jacobs (Princeton University); secretary, Prof. Armin Braun (Rockefeller Institute); treasurer, Prof. H. Clark Dalton (New York University). The othor mombers of the executive committee are : Prof. Clifford Grobstein (newly elected), and Profs. Arthur Galston and Dietrich Bodenstein.

\section{The Association of Clinical Biochemists}

THE Association of Clinical Biochemists has elected the following officers for the session 1960-61: president, Dr. C. P. Stewart ; chairman, Dr. A. L. Latner ; honorary treasurer, Dr. R. Gaddie; honorary editor, Mr. H. Varley ; honorary secretary, Dr. J. H. Wilkinson (Westminster Medical School, Horseferry Road, London, S.W.1).

\section{Announcements}

Mr. A. D. McKnight, executive commissioner of the Australian Atomic Energy Commission, has been elected chairman of the Board of Governors of the International Atomic Energy Agency for the next year.

The eleventh session of the United Nation's Educational, Scientific and Cultural Organization is to be held at Unesco House, Place de Fontenoy, Paris, during November 14-December 13. The main subject for discussion will be International Co-operation for Oceanographic Research.

AN all-day session of the Welsh Soils Discussion Group will be held in the Department of Geography and Anthropology, University College, Aberystwyth, on November 16. The theme will be: "Glaciation in Wales as related to Soil Profile Development". Further information can be obtained from Mr. James A. Taylor, Department of Geography, University College of Wales, Alexandra Road, Aborystwyth.

A symposium on "Inorganic Polymers" is being sponsored by the Chemical Society, and will be held at the University of Nottingham during July 18-21, 1961. Further information can be obtained from the General Secretary, Chemical Society, Burlington House, London, W.1.

THe 1960 meeting of the American Association for the Advancement of Science will be held in New York City during December 26-31. Further information can be obtained from the director of public information for the meeting, Sidney S. Negus, Medical College of Virginia, Richmond, Virginia.

THE Plant Phenolics Group is holding a one-day meeting on "The Stereochemistry of Natural Phenolic Compounds" at the Department of Engineering, University of Bristol, on December 16. Further details can be obtained from the Honorary Secretary of the Group, Low Temperature Research Station, Downing Street, Cambridge.

THE third international conference on "Analogue Computation" will take place in Belgrade during September 4-9, 1961. The conference is being organized by the International Association for Analog Computation. Further information ean bo obtained from L. Radanovic, Yugoslav Committee for Electronics, Telecommunications, Automation and Nuclear Engineering, Tarazije 23/VII, Belgrade. 